Anna Ziółkowska@D, Eliza Oleksy, Paulina Kasperska, Wojciech Stemplowski, Natalia Sokołowska, Remigiusz Sokołowski@, Kornelia Kędziora-Kornatowska®

Department and Clinic of Geriatrics, Collegium Medicum in Bydgoszcz, Nicolaus Copernicus University in Toruń, Toruń, Poland

\title{
Impact of the percentage of muscle and fat tissue and muscle strength on the quality of life of people over 60 years of age
}

\author{
Corresponding author: \\ Anna Ziółkowska \\ Department of Geriatrics, Collegium \\ Medicum Nicolaus Copernicus \\ University in Bydgoszcz \\ 85-094, M Curie-Skłodowskiej Str. 9 , \\ Bydgoszcz, Poland, \\ e-mail: anna.ziolkowska@doktorant.umk.pl
}

Medical Research Journal 2020; Volume 5, Number 3, 148-153 10.5603/MRJ.a2020.0030 Copyright (C) 2020 Via Medica ISSN 2451-2591

\begin{abstract}
Introduction: Physical activity is crucial in a person's life. It has an impact on health, motor and mental fitness. Implementation of physical activity affects the percentage of human body tissues. The aim of the study is to conduct an analysis influence of the percentage of muscle and fatty tissue and muscle strength on the quality of life of people over 60 years of age.

Material and methods: The study was conducted among 86 patients (the average age was: 72) from Geriatrics Clinic, qualified for Geriatric Comprehensive Assessment in scheduled mode. Measurements of anthropometric parameters were performed: 1) for body composition was used TANITA weight; 2) for muscle strength measurement of the upper limbs was used a hand dynamometer; 3) quality of life measurement by the FACIT scale.

Results: In case of the higher percentage of adipose tissue, the lower muscular strength of the patients. In case of the higher percentage of muscle mass, the higher muscular strength of the patients. Correlation of muscle strength $(\mathrm{kg})$ with the quality of life (4 domains measured by FACIT scale) was significant and amounted respectively: physical domain $R=0.34$ ( $p<0.001)$, social domain $R=0.25(p=0.031)$, emotional domain $R=0.27$ ( $p=0.021$ ), functional domain $R=0.35(p<0.001)$.

Conclusions: The results clearly present that the higher muscle strength of older people has an influence on a higher level of quality of life. It is necessary to aware carers of the elderly people that physical activity maintain as much muscle mass and strength as possible which contributes to ensuring the best quality of life for the elderly.

Key words: quality of life of the elderly, muscle strength, physical activity
\end{abstract}

Med Res J 2020; 5 (3): 148-153

\section{Introduction}

Physical activity is an essential element of human life. It plays an important role to maintain health and fitness. The World Health Organization (WHO) and the European Union recommend that elderly people engage in moderate physical activity for at least 30 minutes for 5 days a week or very intense physical activity for at least 20 minutes three days a week. They also recommend exercises that increase muscle strength and endurance - 2-3 times a week [1, 2]. Health benefits gained by physical activity of older people: prevention and/or delay of the development of hypertension and better control of blood pressure; enhances the function of the heart and respiratory system; preservation of metabolic functions and lower risk of diabetes type 2; weight control and reducing the risk of obesity; lower risk of some types of cancers, eg. breast, prostate and colon; lower risk of osteoporosis and fractures, improvement of digestive functions and regulation of bowel movements; preservation and improvement of muscle strength and endurance; maintain motor functions, include strength and motor coordination; cognitive functions and lower risk of depression; reduce the level of stress; creates a better picture of self-esteem, as well as greater enthusiasm and optimism; less absenteeism due to illness; lower risk of falls and delayed appearance of diseases [2]. 
Body composition measurement in the last decade has a lot of interest in sports medicine or fitness clubs as control of effects in training. The results of body fat measurements and their distribution in the body can also be used to predict the risk of cardiovascular or metabolic diseases [4]. Body composition can be measured by various methods: hydrostatic weighing, computed tomography, magnetic resonance imaging, dual-energy X-ray absorptiometers (DXA) and bioelectric impedance analysis (BIA). Most of those methods are hardly available and expensive. A fast, non-invasive, cheap and accurate analysis can be performed by electrical bioimpedance (BIA). This method can be performed in case healthy and sick people, with chronic metabolic diseases, in adults and children. Body composition testing using the BIA method involves measuring impedance, electrical resistance, which consists of soft tissue resistance and reactance through which low-current electrical current is passed $[5,6]$.

Despite knowledge of the positive impact of physical activity on health and quality of life, statistical data from 2017 presented: only every fourth person (27\%) above 60 years of age participates in general motor activities such as jogging and Nordic walking [3].

The purpose of our study was to analyse the influence of the percentage of muscle and fatty tissue and muscle strength on the quality of life people over 60 years of age.

\section{Material and methods}

\section{Participants and procedures}

The study was approved by the Bioethical Committee of the Nicolaus Copernicus University in Torun, Ludwik Rydygier Collegium Medicum in Bydgoszcz. All participants gave written consent for participation in the study.

The study was conducted in Geriatrics ward, Ludwik Rydygier Collegium Medicum in Bydgoszcz, Nicolaus Copernicus University. The duration of the study: September 2016-March 2017. Total study sample comprised 86 participants.

The criteria for inclusion of participants was: age over 60, admission to the Geriatrics Clinic for comprehensive geriatric assessment. On the other hand, exclusion criteria were: major NCD (Neurocognitive Disorders), uncorrected hearing loss or deafness, uncorrected defective eyesight or complete blindness, significant dependence in everyday life - a bedridden person, intake medications which induce depression of the central nervous system (CNS), and less than 6 years of formal education.
All participants underwent: neuropsychological tests, quality of life tests, functional and laboratory tests. The diagnose of mild NCD or lack of NCD was established by the therapeutic team, consists geriatrician, clinical neuropsychologist and physiotherapist. A group of experts identified the severity of cognitive impairment without taking into account etiology. Then, an independent researcher could carry out further functional tests.

\section{Anthropometric instruments}

In our study, we used the BIA method available in TANITA body composition monitor (TANITA BC-545), which allowed the measurement of all major components, include fat, muscle mass, body water contents and more.

Measurement of muscle strength was conducted by a hand dynamometer. It is a simple and useful method of prognostic assessment of functional status, especially in the elderly. The maximum grip force was measured by a hydraulic hand dynamometer. Participants, after instructions, measured by squeezing the dynamometer bar three times with dominant hand and the non-dominant hand. The highest hand force measurement was considered as correct measurement.

\section{Functional tests}

The Activities of Daily Living (ADL) and the Instrumental Activities of Daily Living (IADL) allowed assessing the degree of human independence. ADL scale assesses the ability of self-care in activities such as bathing, using the toilet, getting dressed, functional mobility, self-feeding and defecation control. IADL scale assesses more complex activities, such as: using the telephone, shopping, preparing meals, housekeeping, tinkering, taking medications and money managing $[7,8]$.

The Functional Assessment of Chronic IIIness Therapy (FACIT) is a collection of health-related quality of life (HRQOL) questionnaires which assess multidimensional health status in people with various chronic illnesses. "FACIT" was adopted as the formal name of the measuring system in 1997. FACIT is directed towards the treatment of chronic diseases, it was created as an extension of the known questionnaire "FACT" (Functional Assessment of Cancer Therapy) to other chronic diseases and conditions. Four primary domains are Physical Well-Being, Social/Family Well-Being, Emotional Well-Being, and Functional Well-Being. The FACIT Measurement System now includes over 400 questions. Assessment of each and every one patient is tailored to him/her so that the most relevant questions are asked in administration time (less than 15 minutes) [9]. 


\section{Neuropsychological tests}

The Mini-Mental State Examination (MMSE) is a scale that quantitatively evaluates cognitive function or mental cunning. MMSE explores the most important aspects of mental performance, such as orientation, memory, counting and concentration of attention, remember fresh and language functions. The numerical result obtained by the patient on the MMSE scale reflects the overall level of his cognitive functioning [10].

The Clock Drawing Test (CDT) is the assessment of cognitive impartment based on sketches of a clock completed by a patient. In this test, clinician gives the person under examination a piece of paper, often with a pre-drawn circle, and asks to draw numbers and hands on the clock face; the directions must show the specific time. Evaluation of abnormalities in drawings may include incorrect number positioning, the omission of numbers, incorrect sequencing, no clock hands and the presence of irrelevant writing $[10,11]$

The Geriatric Depression Scale (GDS) was created by Yesavage et al. It is a useful tool to help assess depression in older adults. GDS Long Form is a 30-item questionnaire. Participants respond by answering "yes" or "no" for the questions about how they felt over the last week. The abbreviated version of GDS questionnaire consists 15 questions select from the Long Form of GDS. GDS scale has been translated into Polish and made available for use in clinical practice by Servier Polska [12]. GDS questionnaire is an accurate and reliable screening tool. It can be useful in older people, in case healthy and mentally ill, from mild to moderately cognitively impaired people. It is a widely useful scale in healthcare environments $[12,13]$.

\section{Statistical analysis}

The statistical elaboration of the collected numerical material was initiated from the examination of the conformity of the distribution of the analyzed variables with the normal distribution. For this purpose, the Shapiro-Wilk test was used. In order to calculate the strength of correlation relationships, the Spearman rank correlation coefficient was used. The $p$-value $\leq 0.05$ was assumed to be statistically significant. Strength of correlation (R Spearman): 0 - no correlation; 0-0.3 - weak positive correlation; 0.3-0.5 - moderate positive correlation; $0.5-1$ - strong positive correlation; 1 - functional correlation. Correlation results were presented graphically using scatterplots.

\section{Results}

The study included 86 participants. The average age was 77.22 years, the average body weight was $72 \mathrm{~kg}$, the average height was $159.32 \mathrm{~cm}$ and the average
BMI was 28.36 (Tab. 1). Average body fat content in the examined group was $35.49 \%$, average muscle mass content was $61.25 \%$ and average body water content was $46.57 \%$. Average visceral fat was $12.7 \%$. Average metabolic rate in the examined group was $1417.04 \mathrm{kcal}$ (Tab. 1).

The average muscular strength in the dominant hand was $26.87 \mathrm{~kg}$, while average muscular strength in the non-dominant hand was $24.2 \mathrm{~kg}$ (Tab. 1). The results of the FACIT questionnaire, which investigated the quality of life, are also presented in Table 1.

As a result of the conducted research, following changes was observed: correlation of average muscle strength (in $\mathrm{kg}$ ) to the content of percent adipose tissue was significant $R=(-) 0.35(p<0.001)$. It means that the higher percent content of fat, the lower the muscular strength of patients was observed; Correlation of average muscle strength (in $\mathrm{kg}$ ) to the content of muscle mass was significant $R=0.32(p=0.005)$. It means that the higher percent muscle mass content, the higher muscular strength of the patients was observed; Correlation of muscle strength (in $\mathrm{kg}$ ) to weight (in $\mathrm{kg}$ ) was not significant $\mathrm{p}=0.251$; Correlation of average muscle strength (in $\mathrm{kg}$ ) to height (in $\mathrm{cm}$ ) was not significant $p=0.154$; Correlation of muscle strength (in $\mathrm{kg}$ ) to results of quality of life FACIT questionnaire in the physical domain was significant $R=0.34(p<0.001)$. It means that the higher muscle strength, the higher quality of life level in the physical domain of patients was observed (Fig. 1). Correlation of average muscle strength (in $\mathrm{kg}$ ) with quality of life results from FACIT scale in the social domain was significant $R=0.25(p=0.031)$. It means that the higher muscle strength, the higher quality of life level in the social domain was observed; Correlation of average muscle strength (in $\mathrm{kg}$ ) with quality of life results from FACIT scale in the emotional domain was significant $R=0.27(p=0.021)$. It means that the higher muscle strength, the higher quality of life level in the emotional domain was observed; Correlation of muscle strength (in $\mathrm{kg}$ ) with quality of life results from FACIT scale in the functional domain was significant $R=0.35(p<0.001)$. It means that the higher muscle strength, the higher quality of life level in the functional domain was observed; Correlation of average muscle strength (in $\mathrm{kg}$ ) with quality of life results from FACIT scale (overall) was significant $R=0.40$ ( $p<0.001$ ). It means that the higher muscle strength, the higher quality of life level was observed (Fig. 2). Correlation of muscle strength (in $\mathrm{kg}$ ) with quality of life results from FACIT scale in the domain of fatigue was significant $R=0.31$ ( $p=0.007$ ). It means that the higher muscle strength, the higher quality of life level in fatigue domain was observed; Correlation of muscle strength (in $\mathrm{kg}$ ) with quality of life results from FACIT scale in the religious domain was significant 
Table 1. Results. Basic statistics

\begin{tabular}{|c|c|c|c|}
\hline \multirow[t]{2}{*}{ Anthropometric parameters } & \multicolumn{3}{|c|}{ Group $(n=86)$} \\
\hline & Average score & (-) $95 \% \mathrm{Cl}$ & $(+) 95 \% \mathrm{Cl}$ \\
\hline Weight [kg] & 72.00 & 70.54 & 73.46 \\
\hline Height [cm] & 159.32 & 159.39 & 160.26 \\
\hline BMI & 28.36 & 27.81 & 28.91 \\
\hline Age & 77.22 & 76.39 & 78.05 \\
\hline Body fat content [\%] & 35.49 & 33.75 & 37.24 \\
\hline Content of muscle mass [\%] & 61.25 & 59.68 & 62.83 \\
\hline BMR — basic metabolism [kg] & 1417.04 & 1365.93 & 1468.15 \\
\hline Body water content [\%] & 46.57 & 45.42 & 47.73 \\
\hline Visceral fat / abdominal obesity & 12.70 & 11.89 & 13.50 \\
\hline Muscle strenght — dominant hand [kg] & 26.87 & 24.27 & 29.47 \\
\hline Muscle strenght — non-dominal hand [kg] & 24.20 & 21.82 & 26.58 \\
\hline FACIT — physical domain & 19.61 & 18.37 & 20.86 \\
\hline FACIT — social domain & 19.35 & 17.72 & 20.98 \\
\hline FACIT - emotional domain & 15.35 & 14.19 & 16.51 \\
\hline FACIT — functional domain & 20.69 & 19.32 & 22.06 \\
\hline FACIT — totality & 75.00 & 71.02 & 78.98 \\
\hline FACIT - factor & 0.69 & 0.66 & 0.73 \\
\hline FACIT-F - fatique & 30.30 & 28.16 & 32.44 \\
\hline FACIT-SP-12 & 30.84 & 28.64 & 33.05 \\
\hline
\end{tabular}

$\mathrm{BMI}$ - body mass index; BMR — basal metabolic rate; FACIT — functional assessment of chronic illness therapy

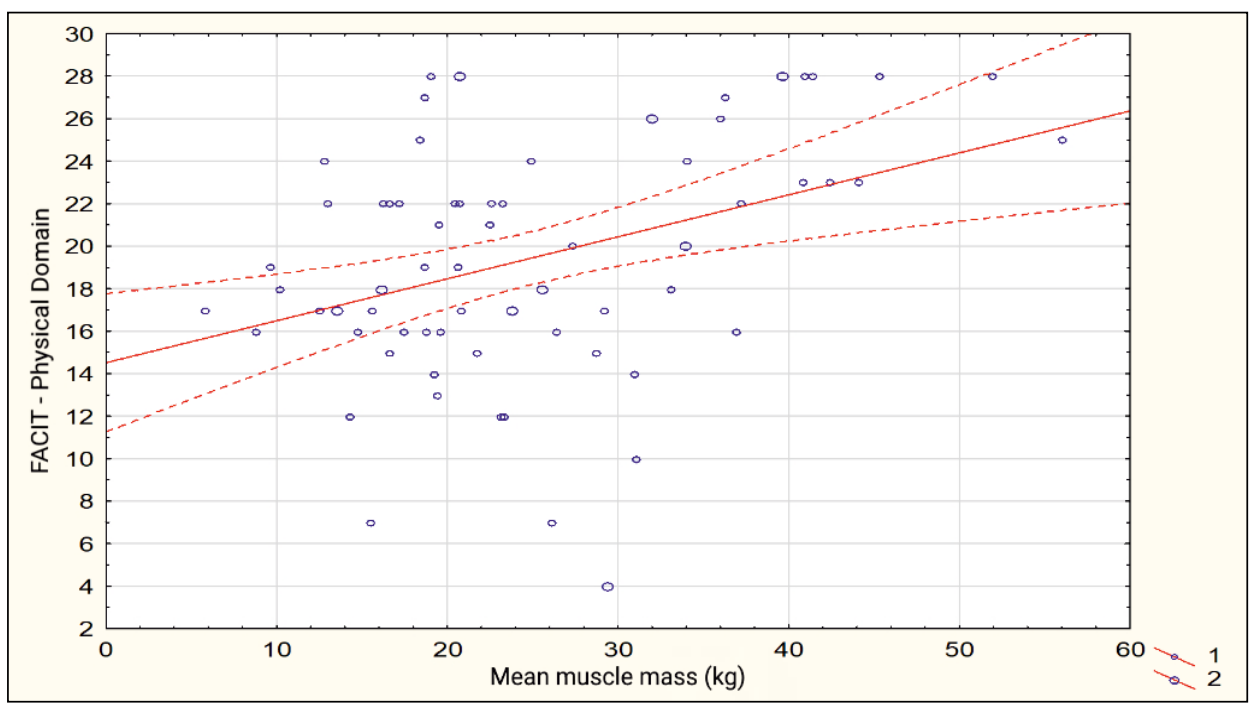

Figure 1. The relationship of mean muscular strength (in $\mathrm{kg}$ ) to the FACIT quality of life results in the physical domain of patients was clear and amounted to $R=0.34(p<0.001)$

$R=0.33(p<0.001)$. It means that the higher muscle strength, the higher quality of life level in the religious domain was observed.

In our study, we noticed a very strong positive correlation between muscle strength and average muscle mass / BMI and also between body fat content and average muscle mass / BMI. A moderate positive correlation exists between the quality of life (FACIT) and muscle strength. Spearman's R correlation also shows high statistical significance $(p<0.05)$ (Tab. 2). 


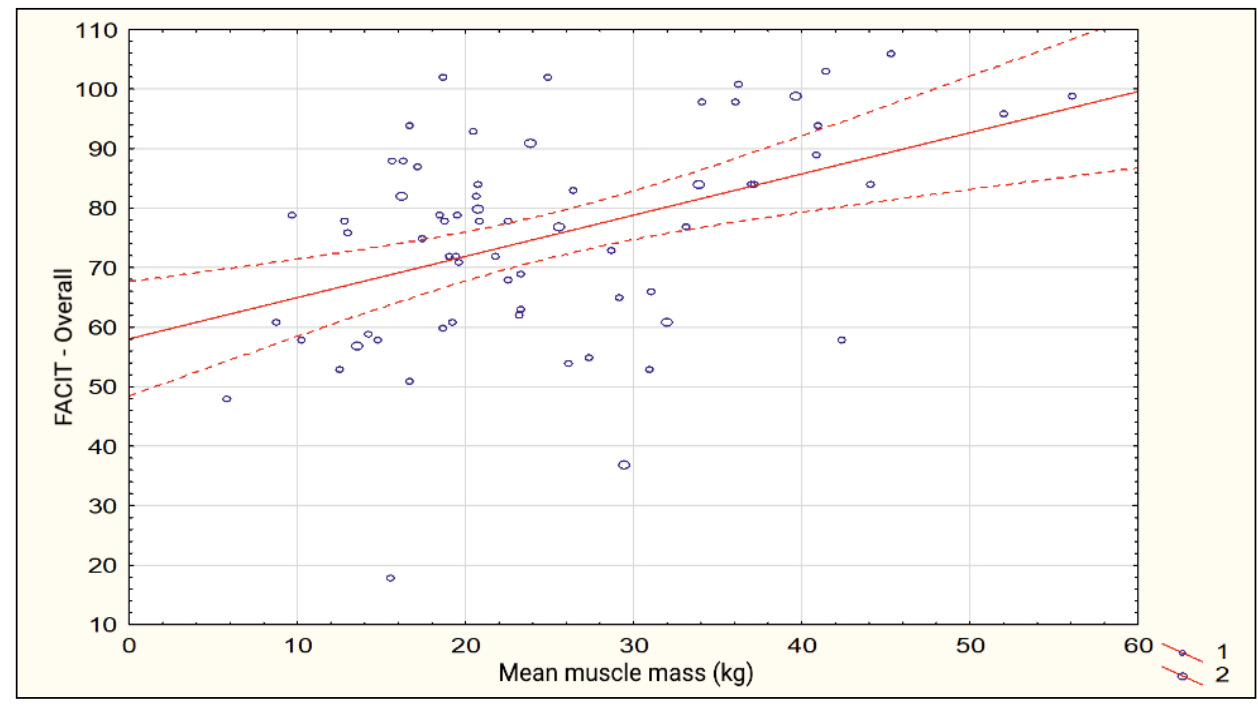

Figure 2. The relationship of mean muscular strength (in $\mathrm{kg}$ ) to the FACIT (overall) quality of life results of patients was clear and amounted to $R=0.40(p<0.001)$

Table 2. Results. Spearman's R correlations

\begin{tabular}{|c|c|c|c|c|c|c|}
\hline \multirow[t]{2}{*}{ A pair of variables } & \multicolumn{2}{|c|}{$\begin{array}{l}\text { Average muscle } \\
\text { strength [kg] }\end{array}$} & \multicolumn{2}{|c|}{$\begin{array}{l}\text { Average muscle } \\
\text { strength/BMI }\end{array}$} & \multicolumn{2}{|c|}{$\begin{array}{l}\text { Average muscle } \\
\text { strenght/muscle mass }\end{array}$} \\
\hline & $\mathbf{R}$ & $\mathbf{P}$ & $\mathbf{R}$ & $\mathbf{P}$ & $\mathbf{R}$ & $\mathbf{P}$ \\
\hline Weight [kg] & 0.13 & 0.251 & -0.1 & 0.382 & -0.24 & 0.047 \\
\hline Height $[\mathrm{cm}]$ & 0.16 & 0.154 & 0.18 & 0.121 & -0.15 & 0.217 \\
\hline BMI & -0.01 & 0.91 & -0.29 & 0.011 & -0.22 & 0.069 \\
\hline Age & -0.18 & 0.111 & -0.07 & 0.537 & -0.13 & 0.263 \\
\hline Body fat content [\%] & -0.35 & $<0.001$ & -0.53 & $<0.001$ & -0.32 & 0.005 \\
\hline Content of muscle mass [\%] & 0.32 & 0.005 & 0.48 & $<0.001$ & 0.27 & 0.018 \\
\hline Body water content [\%] & 0.36 & $<0.001$ & 0.51 & $<0.001$ & 0.30 & 0.009 \\
\hline $\begin{array}{l}\text { Muscle strenght - dominant hand } \\
{[\mathrm{kg}]}\end{array}$ & 0.96 & $<0.001$ & 0.91 & $<0.001$ & 0.88 & $<0.001$ \\
\hline $\begin{array}{l}\text { Muscle strenght - non-dominal } \\
\text { hand }[\mathrm{kg}]\end{array}$ & 0.91 & $<0.001$ & 0.83 & $<0.001$ & 0.82 & $<0.001$ \\
\hline FACIT - physical domain & 0.34 & $<0.001$ & 0.22 & 0.068 & 0.38 & 0.001 \\
\hline FACIT - social domain & 0.25 & 0.031 & 0.16 & 0.192 & 0.13 & 0.266 \\
\hline FACIT - emotional domain & 0.27 & 0.021 & 0.22 & 0.07 & 0.32 & 0.007 \\
\hline FACIT — functional domain & 0.35 & $<0.001$ & 0.30 & 0.012 & 0.37 & $<0.001$ \\
\hline FACIT — totality & 0.40 & $<0.001$ & 0.30 & 0.013 & 0.38 & $<0.001$ \\
\hline FACIT - factor & 0.40 & $<0.001$ & 0.30 & 0.013 & 0.38 & $<0.001$ \\
\hline FACIT-F - fatique & 0.31 & 0.007 & 0.20 & 0.100 & 0.35 & $<0.001$ \\
\hline FACIT-SP-12 - religious domain & 0.33 & $<0.001$ & 0.32 & 0.008 & 0.42 & $<0.001$ \\
\hline
\end{tabular}

$\mathrm{BMI}$ - body mass index; FACIT — functional assessment of chronic illness therapy 


\section{Discussion}

Old age is associated with the accumulation of specific problems related to health, therefore it is important to conduct research on the quality of life and the factors affecting it. The Functional Assessment of Chronic Illness Therapy (FACIT) is a comprehensive set of quality of life $[14,15]$. The study clearly shows that the increase of fatty tissue in the body, the mass of muscle tissue decreases, which is associated with a reduction of the quality of life. It would be necessary to take into account the division into sex in the future study. It seems to be a good idea to increase the number of participants in the study divided into men and women section and category of physically active people / lack of physical activity. It would increase the accuracy of results of the study. The fact should be taken into account, that women have different content of adipose tissue and muscle mass in the body compared to the opposite gender. Also, the study does not include patients diseases that may contribute to increase in fat content or loss of muscle mass. Therefore, in the future study should take into account exclusion criteria such as diseases e.g. multiple sclerosis, diabetes or Parkinson's disease and certain medications. It is worth considering that in the future examination the average BMI of patients will be within the norm. It is important to make adult middle-aged people aware of the importance of physical activity and high muscle strength on quality of life, especially in elderly age.

We can see a strong correlation in the functional and physical domain, due to the high muscle mass and strength, which is associated with fitness and physical activity and can also be associated with greater social activity. The relationship in the emotional domain and muscle strength can result directly from good physical fitness or because of greater social activity (due to functional capabilities). Authors Kaczmarczyk and Trafiałek point out that increasing the activity older people prevents loneliness and isolation, as well as preserving independence to the late years of life. Gębska-Kuczerowska in a survey conducted research among people over 65 years old presented that physically active people had better physical and mental condition [16]. Study conducted by Boston Claude D. Pepper Older Americans Independence Center, and the Boston Rehabilitation Outcomes Center among older adults showed that declining muscle mass, strength, power, and physical performance are independent contributing factors increased fear of falling, while declines of muscle mass and physical performance contribute to the deterioration of quality of life [17]. To confirm the causal relationship between the content of muscle and fatty tissue in the human body and the quality of life, it is worth conducting research, after activation of the social life of people over 60 , it will be examined whether there has been an increase in muscle tissue content and/or a decrease in body fat.

\section{Conclusions}

The results clearly present that the higher muscle strength of older people has an influence on a higher level of quality of life. It is necessary to aware carers of the elderly people that physical activity maintain as much muscle mass and strength as possible which contributes to ensuring the best quality of life for the elderly.

\section{Conflict of interest}

Authors report no competing interests.

\section{References}

1. Wieczorowska-Tobis K, Kostka T, Borowicz AM. Fizjoterapia w geriatrii. PZWL, Warszawa 2011

2. Rowiński R, Dabrowski $A$, et al. Aktywność fizyczna Polaków w wieku podeszłym; Mossakowska M., Więcek A., Błędowski P. Aspekty medyczne, psychologiczne, socjologiczne i ekonomiczne starzenia się ludzi w Polsce. Termedia Wydawnictwo Medyczne, Poznań. 2012; 3: 531-548.

3. Główny Urząd Statystyczny. Uczestnictwo w sporcie i rekreacji ruchowej w 2016 r. Warszawa 2017

4. Hemmingsson E, Uddén J, Neovius M. No apparent progress in bioelectrical impedance accuracy: validation against metabolic risk and DXA. Obesity (Silver Spring). 2009; 17(1): 183-187, doi: 10.1038/oby.2008.474, indexed in Pubmed: 18997678.

5. Lewitt A, Mądro E, Krupienicz A. Podstawy teoretyczne i zastosowania analizy impedancji bioelektrycznej (BIA). Endokr Otył Zab Przem Mat. 2007: 4: 79-84.

6. Major-Gołuch A, Miazgowski T, Krzyżanowska-Świniarska B, et al. Comparison of fat mass measurements in young, healthy, normal-weight women by bioelectricimpedance analysis and dual-energy X-ray absorptiometry. Endokrynologia, Otyłość i Zaburzenia Przemiany Materii. 2010; 6(4): 189-195.

7. Katz S, Downs TD, Cash HR, et al. Progress in development of the index of ADL. Gerontologist. 1970; 10(1): 20-30, doi: 10.1093/geront/10.1_part_1.20, indexed in Pubmed: 5420677.

8. Lawton MP, Brody EM. Assessment of older people: self-maintaining and instrumental activities of daily living. Gerontologist. 1969; 9(3): 179-186, indexed in Pubmed: 5349366.

9. Webster K, Cella D, Yost K. The functional assessment of chronic illness therapy (FACIT) measurement system: properties, applications, and interpretation. Health Qual Life Outcomes. 2003; 1: 79

10. Kotapka-Minc S. Znaczenie badania neuropsychologicznego w diagnostyce otępienia. Polski Przegląd Neurologiczny. 2007; 3(2): 61-68.

11. Harbi Z, Hicks $Y$, Setchi R. Clock drawing test interpretation system. Procedia Computer Science. 2017; 112: 1641-1650, doi: 10.1016/j. procs.2017.08.259.

12. Albiński R, Kleszczewska-Albińska A, Bedyńska S. Geriatryczna skala depresji (GDS). Trafność i rzetelność różnych wersji tego narzędzia — przegląd badań. Psychiatria Polska. 2011; 45(4): 555-562

13. Greenberg SA. Geriatric depression scale (GDS). Practical Guide to the Care of the Geriatric Patient. 2007: 646-647, doi: 10.1016/b9780-323-03671-9.50021-6.

14. Cella D, Nowinski CJ. Measuring quality of life in chronic illness: the functional assessment of chronic illness therapy measurement system. Arch Phys Med Rehabil. 2002; 83(12 Suppl 2): S10-S17, doi: 10.1053/apmr.2002.36959, indexed in Pubmed: 12474167.

15. Brady MJ, Cella DF, Mo F, et al. Reliability and validity of the Functional Assessment of Cancer Therapy-Breast quality-of-life instrument. J Clin Oncol. 1997; 15(3): 974-986, doi: 10.1200/JCO.1997.15.3.974, indexed in Pubmed: 9060536.

16. Grzanka-Tykwińska A. Znaczenie wybranych form aktywności w życiu osób w podeszłym wieku. Gerontologia Polska 2010; 18. ; 1: 29-32.

17. Trombetti A, Reid KF, Hars M, et al. Age-associated declines in muscle mass, strength, power, and physical performance: impact on fear of falling and quality of life. Osteoporos Int. 2016; 27(2): 463-471, doi: 10.1007/s00198-015-3236-5, indexed in Pubmed: 26194491. 